\title{
Teodor Oancă, Contribuții onomastice, Editura Grafix, Craiova, 2018, 196 p.
}

\author{
Adelina Emilia Mihali ${ }^{\star}$ \\ "Sextil Puşcariu" Institute of Linguistics and Literary History, Str. Emil Racoviță 21, 400165, Cluj-Napoca, Romania
}

Teodor Oancăs new book, Contribuții onomastice [Contributions in Onomastics], published in 2018 at Grafix Publishing House completes the author's works in Romanian anthroponomy. Having a vast experience in the study of people's names, Teodor Oancă offers a model of analysing the Romanian surnames extracted from $\mathrm{Baza}$ de date antroponimice a României [Romania's anthroponomy database] constituted in 1994 at Faculty of Letters, Craiova University. As there is no complete Frequency dictionary of surnames in Romania, the anthroponomical material valorised by Teodor Oancă frames a general picture of surnames, and the statistic indications on regions and counties, even if they are not up to date, are still very useful in studying onomastics. The accessible language, the linguistic and historical arguments the author uses make the volume we are referring to a guide mark in anthroponomical analysis. Actually, Teodor Oancăs whole scientific activity proved that anthroponomical research implies an interdisciplinary approach and also the fact that one cannot draw the right conclusions on the origin, evolution and dynamics of people's names without a synchronic and diachronic perspective. Moreover, we have to mention the important role the anthroponomy plays in Romanian toponymy, thus, any work on people's names that confirms the existence of an anthroponym in different parts of the country facilitates the toponymical interpretation.

The work reunites, as the author mentions in the Foreword, a series of articles previously published in scientific reviews or in collective volumes: Catagrafia Episcopiei Râmnicului de la 1845. Aspecte socioantroponimice [The catagraphy of Râmnic Diocese from 1845. Socio-anthroponomical aspects] (p. 82-90), Reconstituirea ariei dialectale Agud [The reconstitution of dialectal area Agud] (p. 91-96), Localizări dialectale și arii antroponimice [Dialectal localizations and anthroponomical areas] (p. 96-98), De la termeni dialectali muntenești la nume de familie [From Wallachian dialectal terms to surnames] (p. 99-105), Numele personal activ [Active personal name] (p. 105-109), Nume de familie derivate cu sufixul-escu. Considerații statistice [Surnames derived with - escu. Statistic considerations] (p. 110131), Originea personală exprimată prin derivarea cu sufixele -ean, -eanu [Personal origin expressed by derivative suffixes -ean, -eanu] (p. 132-142), Antroponime derivate cu sufixul -ete [Anthoponyms derived with the suffix -ete] (p. 143-146), Valoarea de sufix de apartenență a unor sufixe diminutivale sau augmentative [Affiliation value of some diminutive or augmentative suffixes] (p. 147-149), Nume de localități argeșene [Names of localities in Argeș] (p. 150-155), Nume de familie moldovene (I) [Moldavian surnames (I)] (p. 156-160), Nume de familie moldovene (II) [Moldavian surnames (II)] (p. 161164), Nume de familie din Băilești, județul Dolj [Surnames in Băilești, Dolj county] (p. 165-182), Români cu nume sîrbești sau maghiare [Romanians having Serbian and Hungarian names] (p. 183-187), and two new studies placed at the beginning of the book: Nume de familie românești provenite de la nume biblice și calendaristice [Romanian surnames originating in Biblical and calendar names] (p. 1565), Rolul impactului antroponimic in conservarea unorimprumuturilexicale [The role of anthropoymic impact on preservation of lexical borrowings] (p. 6681). A Cuvint inainte Foreword (p. 5-7), a Bibliografie [Bibliography] (p. 8-12) and a list of Sigle pentru regiuni, sigle pentru județe [Abbreviations for regions and counties] (p. 13) open the volume, which is completed by Concluzii [Conclusions] (p. 188189) and a Rezumat [Abstract] in French (p. 190191) and in English (p. 192-193). The fact that this work is a collection of older articles published in different reviews and volumes make it even more valuable as it represents a support for the researchers

^Email address: adelinatatar@yahoo.com. 
in onomastics, facilitating the access to information on the study of people's names.

The author grouped his articles, variable as regarding their dimensions, according to their themes, following the relationship of anthroponomy with etymology, history, dialectology or toponymy and also the structure of surnames or surnames specific to Romanian provinces.

The first chapter of the book, Nume de familie românești provenite de la nume biblice și calendaristice [Romanian surnames originating in Biblical and calendar names], brings into discussion the relationship between the Romanization of Dacians, the Christianising process and anthroponomy. Starting from the idea that "dacă din punct de vedere militar, social și cultural autoritatea romană s-a impus fără opreliști, cele dintîi manifestări de existență a noii religii pe teritoriul Daciei au fost sporadice, lipsite de forme de organizare" [as from military, social and cultural point of view, the Roman authority manifested itself without limits, the first signs of the new religion in Dacia were sporadic, lacking organization] (p. 15), the author reviews the phases in Christianising Dacia and the Romanization through Christianity, proved by historical and linguistic arguments and also the phases in Romanian anthroponomy development: from native appellatives which became nick-names and bynames then surnames, to biblical/calendar names and to the role of church in their spreading and consolidation. The theoretical considerations are completed by two annexes, one of them registering 170 primary surnames originating in biblical or calendar Christian names, and also diminutive, derivative forms or variants, for which the frequency per regions and counties is indicated, and the other one, actually a part extracted from the first annex, which contains the most frequent 86 surnames.

In the second chapter, Rolul impactului antroponimic in conservarea unor imprumuturi lexicale [The role of anthroponomical impact on preserving some lexical borrowings] the author discusses the problem of lexical elements belonging to substratum and the way they were preserved as a result of them being used as anthroponyms, usually nick-names, if "un sens al lui [al numelui comun] să fie asociat cu o trăsătură fizică, psihică, morală sau de comportament a cuiva" [one meaning of the name is associated with someone's physical, psychological, moral or behavioural feature] (p. 68). Mentioning the most known researches on the substratum, Teodor Oancă exemplifies the anthroponymic impact, defined as "posibilitatea unui nume comun de a trece în clasa numelor proprii și de a fi reținut în limba latină datorită sprijinului acordat de antroponimul rostit zilnic în familie, dar și în relațiile sociale, și care făcea posibil ca apelativul să se impună în limbă în locul cuvintului latin echivalent" [the possibility that a common name to pass into proper names class and to be kept into Latin because of the support the anthroponym gave by being used daily in familial and social relationships, thus making possible that the appellative to assert itself in language instead of its Latin equivalent] (p. 5). The article is completed by 72 surnames, which, as the author states, preserve autochthonous words identified by Grigore Brîncus, and have an anthroponymic impact (p. 71) and which, due to "prin distribuția lor de azi în teritoriu, (...) ne dovedesc prezența în spații largi a apelativelor de la care provin" [their distribution nowadays (...) prove the presence of the appellative they come from on large areas], thus "putem spune că încă din timpul însușirii limbii latine de către traco-daci aceste cuvinte nu arătau că aparțin unor subdiviziuni teritoriale ale limbii vorbite de ei" [we can assert that starting even with the Traco-Dacians learning Latin period, these words did not show any evidence they belonged to territorial subdivisions of the language they spoke] (p. 71). Regarding the registered surnames, we consider it would have been useful to be indicated the appellatives they come from and their meaning, where necessary, in order to eliminate any vagueness, especially in cases of homonymy and derivation. For instance, without a clear specification, a nonspecialist reader could relate the surname Bască, included in the above mentioned list, to the French borrowing bască 'beret', more common in everyday speech than the autochthonous bască 'wool cut off sheep'. This information would also make clear the situation of derivates from appellatives considered as belonging to the autochthonous lexical layer which set themselves as surnames, such as Copăcel or Urdaș. We also think that there is a mere mistake in the chapter title as the study discusses mostly the situation of the inherited words (especially substratum, but also Latin ones) and less of the borrowed ones in which case the title should have contained the syntagm "lexical heritage" or 
"inherited words" instead of "lexical borrowings", thus explaining the list of surnames containing Ceară < ceară 'wax' < lat. cera.

The third chapter, Catagrafia Episcopiei Râmnicului de la 1845. Aspecte socioantroponimice [The catagraphy of Râmnic Diocese from 1845. Socioanthroponomical aspects], offers the reader an image of the personal denominative system at the middle of the 19th century and also of the principles at the basis of naming, partially kept until today: "numele bunicului s-a transmis nepotului" [the name of the grandfather taken by the grandson] (p. 83), "în cazul în care copilul purta numele tatălui sau al bunicului exista posibilitatea ca diferențierea de numele acestuia să se facă printr-un diminutiv sau hipocoristic..." [when the child bore the name of the father or grandfather, there was the possibility to be differentiated through a diminutive or a hypocoristic...] (p. 87). The author introduces two syntagms: complementary name or byname, defined as "antroponimul care însoțește numele personal al celui recenzat, realizîndu-se o structură binară, al doilea cuvint putînd fi considerat ca nume de familie la acea dată" [the anthroponym that accompanies the personal name of the one who is registered, in a binary structure, the second word being able to be considered surname at that time] (p. 83) and extended anthroponym, explained as "structura antroponimică prin care este menționat numele complet al tatălui persoanei recenzate" [the anthroponymic structure that mentions the complete name of the registered person's father]. The given examples and the explanations regarding the derivates or the Slavonic words sin, brat, zen used in denominative structures at that time help the researchers and impose a model of analysis for the anthroponomy in historical documents.

The next three chapters approach the interdependence relationship between anthroponomy and dialectology: "uneori frecvența concentrată într-o zonă a unui nume de familie, care face trimitere la un cuvînt dialectal, poate fi un indiciu că acolo termenul dialectal a fost activ în trecut, apoi a dispărut din uz, el nemaifiind înregistrat în anchetele dialectale" [sometimes, the frequency of a surname in a certain area relates to a dialectal word which could have been active in the past, then disappeared and was not registered during the dialectal inquiries] (p. 96). Thus, the author reconstructs the dialectal area of agud 'mulberry tree' in Crișana based on the frequency of Agud surname, he locates some dialectal terms in counties where they are mentioned only as surnames or identifies specific features of vernaculars belonging to a subdialect in the structure of anthroponyms.

A theoretical chapter, Numele personal activ [Active personal name] explains, on the one hand, the syntagm in the title, on the other hand, the connection between the official and the popular personal denominative system. The next four articles approach the surnames structure, especially the derivates with the suffixes -escu, -ean/-eanu, - ete. The chapter Nume de familie derivate cu sufixul -escu. Considerații statistice [Surnames derived with the suffix -escu. Statistical considerations] includes, besides the theoretical part referring to the meaning of the suffix, the origin of the reference name and the age of these denominative forms, two annexes. The first one contains surnames registered in Baza de date antroponimice a Români [Romania's anthroponomical database], in 1994, specifying the anthroponym at the basis of derivation and the frequency of each name. The second annex is a catalogue of surnames derived with the suffix - escu presented in Constantin Sion's Arhondologia Moldovei. The anthoponymic material presented by Theodor Oancă represents a corpus which can be valorised by other linguists and is very useful in studying the Romanian onomastics. When analysing the surnames derived with -ean/-eanu, the author takes into consideration only those anthroponyms for which, as the author says, the suffix -ean has the quality of affiliation, being identical in meaning with -escu, namely surnames derived from an anthroponym. We consider here a small observation: although the author carefully selected his unquestionable examples, for some names mentioned in Annexes, the suffix could indicate, when no supplementary data are available, both the personal origin of the bearer and the local one, as there are localities with names that come from the anthroponyms specified by the author. For instance, the surname Blăgean, more frequent in Iași and Vaslui counties, is related to the anthroponym Blaga, but there are two villages named Blaga in Moldova (one in Iași county and the other in Bacău) a fact that could have caused that the registered names to be due to the bearers' local origin. 
Completing the previous chapters referring to derived surnames, Nume de localități argeșene [Locality names in Arges] analyses oiconyms based on either a group name that comes from first/surnames, nicknames, bynames, or from personal names. The author explains in an accessible language the syntagm "group names", the derivative processes that brings to their formation and also the values of the suffixes identified in their structure, all of these completed with historical information.

Nume de familie moldovene (I) [Moldavian surnames (I)] discusses a series of appellatives considered as belonging to Moldavian subdialect, which passed to personal denomination, first as nicknames, then as official surnames. The author mentions in Annex both the surname preserving the appellative and the anthroponyms coming from a derivate of the common noun (Perja - Perjeru, Prisacă Prisăcariu, Prisăcaru, Prisecariu), selectively giving information on the derivative process. In Nume de familie moldovene (II) [Moldavian surnames (II)] the author approaches surnames coming from feminine personal names with the genitive possessive article $a$. The information on their frequency in the country and in Moldova (between brackets) are illustrative for their spreading countrywide and for population movements.

The last but one chapter, Nume de familie din Băilești, județul Dolj [Surnames in Băilești, Dolj county], is a structural, etymological and historical analysis of 574 surnames from Băilești, illustrating "dinamica deplasării în timp a unor persoane" [the dynamics of people's movement in time] (p. 167), the socio-cultural relationships between Bulgarian immigrants and natives and their influence on anthroponomy. The study represents, for sure, a model in approaching an anthroponomical (micro)monograph, both from the analysis point of view and also from the point of view of the documentation, history recall and interdisciplinary method the author brings into his scientific activity.

We cannot overlook the last chapter of the book, Români cu nume sîrbești sau maghiare [Romanians having Serbian or Hungarian names] which, even though reduced in dimensions, offers clear and convincing arguments for the changes of Romanian surnames in areas under Hungarian administration in the $19^{\text {th }}$ century. The problem of the magyarization of personal names is an older one and it deserves detailed analysis in order to demonstrate to our colleagues in Hungary that the Hungarian surnames are not a proof of the bearers' ethnic origin, but they represent the Hungarian correspondent of the Romanian names given to their descendants, as their bilingualism (Hungarian and Romanian) was succeeded by monolingualism (Hungarian) ${ }^{1}$.

The work Contribuţii onomastice [Contributions in Onomastics] signed by Teodor Oancă completes the list of researches in Romanian anthroponomy and it represents an important working tool for linguists in general, and onomasts. As we have previously mentioned, the author's contributions complete the Dicționarul de frecvență a numelor de familie din România [Frequency dictionary of surnames in Romania], volume I, letters A-B, and offers support for those who study onomastics. Our minor observations do not diminish the value of the book and its importance to the Romanian onomastics bibliography.

\footnotetext{
${ }^{1}$ See János N. Fodor, Personal Names and Ethnicity: The Geolinguistic Research of Historic Personal Names in Hungary, in “Onomastica Uralica”, no. 13 (2018), Debrecen-Helsinki, p. 55-64.
} 